\title{
Konstruksi Pemberitaan Kompas.com dan Republika.co.id tentang Kebijakan Pasangan Turis Bukan Muhrim Menginap Sekamar di Arab Saudi
}

\author{
https://doi.org/10.25008/caraka.v1i2.46 \\ AHMAD SURYANA \\ Universitas Budi Luhur, Jakarta - Indonesia
}

\begin{abstract}
Saudi Arabia is an ultraconservative country that applies Islamic laws in its legislation in various sectors in the country, including the tourism sector. Saudi Arabia began to look at the tourism sector in an effort to get out of its dependence on petroleum. Before 2018, there were many strict regulations that restrain women in Saudi Arabia, including the prohibition of driving and traveling without mahram. However, a number of strict rules are now experiencing significant easing, one of which is related to the prohibition of non-married couples staying in one room. This policy only applies to foreign tourists who come to Saudi Arabia with a tourist visa. In this paper the author tries to analyze online media coverage (kompas.com) and (republika.co.id) related to the Saudi Arabian government policy that allows couples of foreign tourists not husband and wife to stay in one room, namely by using analysis of framing Zhongdang Pan and and Gerald M. Kosicki.
\end{abstract}

Keywords: Saudi Arabia; kebijakan; konstruksi pemberitaan; pariwisata; bukan muhrim.

\begin{abstract}
ABSTRAK
Arab Saudi merupakan negara ultrakonservatif yang menerapkan hukum Islam dalam perundangundangannya di berbagai sektor termasuk sektor pariwisata. Arab Saudi mulai melirik sektor pariwisata dalam upaya keluar dari ketergantungan terhadap minyak bumi. Sebelum tahun 2018, banyak peraturan ketat yang mengekang perempuan di Arab Saudi, diantaranya larangan menyetir dan bepergian tanpa mahram. Sejumlah aturan ketat tersebut kini mengalami pelonggaran, salah satunya dihapusnya larangan pasangan bukan suami isteri menginap dalam satu kamar bagi turis asing yang datang ke Arab Saudi. Studi ini menganalisis pemberitaan kompas.com dan republika.co.id terkait kebijakan pemerintah Arab Saudi memperbolehkan pasangan turis asing bukan suami isteri menginap dalam satu kamar. Analisis yang digunakan adalah framing Zhongdang Pan dan dan Gerald M. Kosicki.
\end{abstract}

Kata Kunci: Saudi Arabia; kebijakan; konstruksi pemberitaan; pariwisata; bukan muhrim.

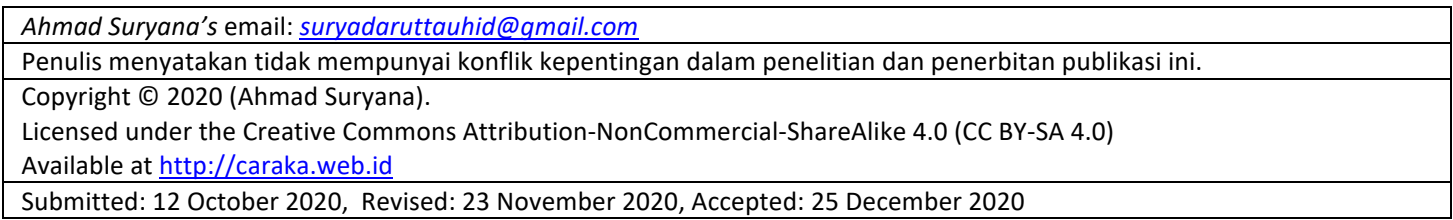




\section{PENDAHULUAN}

Perubahan terbesar di bidang komunikasi sejak munculnya televisi adalah penemuan internet sebagai jaringan komputer yang telah mendorong media massa memiliki website untuk menyalurkan berita (Severin dan Tankard, 2014). Penemuan teknologi itu menyebabkan media online bermunculan, antara lain Kompas.com dan Republika.co.id di Indonesia yang menyiarkan berita secara cepat. Kecepatan menyiarkan berita merupakan kelebihan dari media online (Romli, 2012: 20).

Berita yang disiarkan sesungguhnya dihasilkan melalui proses framing (pembingkaian). Sebuah berita dikonstruksi dari sebuah fakta atau peristiwa oleh wartawan dengan membingkainya. Wartawan melihat sebuah fakta atau peristiwa kemudian membingkainya dalam sebuah berita untuk kemudian disiarkan kepada khalayak.

Dua media membingkai satu berita dari sumber yang sama, Al-Jazeera, namun menampilkannya dari sudut pandang yang berbeda sehingga menghasilkan interpretasi yang berbeda pula dari masing-masing khalayak dalam berita kebijakan Arab Saudi yang meperbolehkan pasangan turis bukan suami isteri menginap dalam satu kamar.

Kebijakan Arab Saudi itu demi menggairahkan sektor pariwisata negara tersebut untuk keluar dari ketergantungan terhadap minyak. Berita kebijakan Arab Saudi itu mendapatkan perhatian cukup besar di sejumlah media-media di Indonesia, termasuk Kompas.com dan Republika.co.id dengan headline yang berbeda-beda.

Perbedaan tersebut terjadi karena setiap media memiliki bingkai berita yang tidak sama dalam melihat fakta atau sebuah peristiwa. Perbedaan tersebut terlihat pada berita yang disampaikan kepada khalayak. Sisi mana yang dianggap penting dan perlu untuk ditampilkan kepada khalayak dan sisi mana yang dianggap tidak penting sehingga tidak perlu ditampilkan kepada khalayak, ini semua dipengaruhi oleh bagaimana suatu media menyusun beritanya.

\section{KERANGKA TEORI}

Internet telah diramalkan jauh sebelum kebaradaannya tiba, bahwa jaringan akan menjadi bentuk terpenting dari transmisi media. Pengembangan jaringan telah dimulai sejak 1960an. Saat ini media memiliki jaringan internet yang menghubungkan komputer pribadi hingga komputer super, saling berhubungan sepanjang masa. Layanan yang diberikan internet saat ini sangat beragam sesuai dengan kebutuhan masyarakat yang melahirkan dunia virtual.

Jaringan internet membuat media berinovasi ke segala lini dan paling adaptif dengan kebutuhan masyarakat, sehingga hampir semua media dan kebutuhan masyarakat dapat dikoneksikan kedalam jaringan-jaringan internet (Bungin, 2003:48) serta berinteraksi dalam suatu platform: media online, terbit di dunia maya.

Media online merupakan salah satu jenis media massa yang popular dan bersifat khas, berjaringan teknologi informasi dengan menggunakan internet (Yunus, 2010: 27). Online Media adalah tatanan baru yang terus mengalami perkembangan (Pavlik, 2004:45). Dalam penggunaannya, online media sering disertai dengan hypertext, yaitu teks online yang dihubungkan ke halaman lain pada sebuah web melalui kode HTML (Pavlik, 2004:28).

Media online juga menyiarkan berita. Berita, dalam pandangan Fishman (1980), bukan suatu refleksi atau distorsi dari realitas yang ada di luar sana. Yang menjadi fokus bukan apakah berita merefleksikan realitas atau apakah berita distorsi atas realitas, namun apakah berita sesuai atau bias terhadap kenyataan yang digambarkannya.

Refleksi merupakan praktik pekerja organisasi dalam memproduksi berita, sehingga berita menjadi apa yang pembuat berita buat (Eriyanto 2002: 100). Refleksi yang 
ditampakkan berita memiliki pemaknaan dan pemahaman yang berbeda di tiap medianya, karena pemaknaan dan pemahaman suatu fakta atau realitas dipengaruhi oleh ideologi media.

Peter Dahlgren (dalam Eriyanto 2002) mengatakan, realitas sosial menurut pandangan konstruktivis (fenomenologis) adalah produksi manusia, hasil proses budaya, termasuk penggunaan bahasa. Melalui penggunaan bahasa sebagai sistem simbol yang utama, para wartawan mampu menciptakan, memelihara, mengembangkan, bahkan meruntuhkan suatu realitas (Eriyanto 2002).

Menurut Schudson (1995), berita adalah hasil konstruksi sosial yang selalu melibatkan pandangan, simbol dan nilai-nilai. Bagaimana realitas dijadikan berita tergantung pada bagaimana fakta itu dipahami dan dimaknai. Apabila proses pemaknaan selalu menggunakan simbol unsur nilai-nilai tertentu maka mustahil berita merupakan wajah atau pencerminan dari suatu realitas itu sendiri. Maka peristiwa yang sama bisa jadi menghasilkan berita yang berbeda karena adanya perbedaan cara melihat dalam hal ini cara membingkainya, namun perbedaan realitas itu pada akhirnya dianggap sesuatu hal yang wajar.

\section{METODOLOGI}

Penelitian ini merupakan penelitian teks media dengan menggunakan analisis framing. Analisis framing termasuk ke dalam pandangan konstruksionis. Artinya setiap berita yang sampai ke pembaca telah dikonstruksikan oleh media massa. Pandangan konstruksionis menilai, berita yang sampai ke pembaca adalah berita yang subjektif, bukan objektif seperti pandangan para kaum positivisme. Pemilihan metode analisis framing dilakukan karena metode ini melihat bagaimana sebuah peristiwa itu dibingkai di dalam pemberitaan.

Analisis framing secara sederhana digambarkan sebagai analisis untuk mengetahui bagaimana realitas (peristiwa, aktor, kelompok, atau apa saja) dibingkai oleh media. Pembingkaian tersebut tentu saja melalui konstuksi. Realitas sosial dimaknai dan dikonstruksi dengan makna tertentu. Peristiwa dipahami dengan bentukan tertentu. Hasilnya pemberitaan media pada sisi tertentu atau wawancara dengan orang-orang tertentu. Semua elemen tersebut tidak hanya bagian dari teknik jurnalistik tetapi menandai bagaimana sebuah peristiwa dimaknai dan di tampilkan (Eriyanto, 2002: 8).

Model analisis framing yang digunakan pada penelitian ini adalah Zhongdang Pan dan Gerald M Kosicki yang mendefinisikan framing adalah proses membuat suatu pesan lebih menonjol, menempatkan informasi lebih daripada yang lain sehingga khalayak lebih tertuju pada pesan tersebut (Eriyanto, 2009). Selain itu peneliti menetapkan menggunakan model Zhongdang Pan dan Gerald M Kosicki karena keempat struktur perangkat analisis framing yakni sintaksis, skrip, tematik, dan retoris membantuk suatu tema yang saling berkaitan dalam sebuah elemen konstruksi pemberitaan.

Struktur sintaksis mengacu pada susunan kata atau ungkapan yang menjadi kalimat. Sintaksis dalam hampir setiap wacana berita memiliki karateristik piramida terbalik, yang terdiri dari headline, lead, episodes, background, closure. Headline merupakan aspek sintaksis dan wacana berita dengan tingkat kemenonjolan yang tinggi, yang menunjukan kecenderungan berita. Lead adalah perangkat sintaksis lain yang sering digunakan. Lead yang baik umumnya memberikan sudut pandang dari berita, menunjukan perspektif tertentu dari peristiwa yang diberitakan (Eriyanto, 1993).

Struktur Skrip berhubungan dengan bagaimana wartawan mengisahkan atau menceritakan peristiwa ke dalam bentuk berita. Struktur ini melihat bagaimana strategi cara bercerita atau bertutur dipakai oleh wartawan dalam mengemas peristiwa kedalam bentuk 
berita.

Struktur Tematik berhubungan dengan bagaimana wartawan mengungkapkan pandangannya atas peristiwa ke dalam proposisi, kalimat atau hubungan antarkalimat yang membentuk teks secara keseluruhan. Struktur ini akan melihat bagaimana pemahaman itu diwujudkan dalam bentuk yang lebih kecil. Eriyanto menjelaskan bahwa struktur tematik dapat diamati dari bagaimana peristiwa itu diungkapkan atau dibuat oleh wartawan.

Struktur sintaksi berhubungan dengan pernyataan bagaimana fakta yang diambil oleh wartawan akan ditempatkan pada skema atau bagan berita, maka struktur tematik berhubungan dengan bagaimana fakta itu ditulis. Bagaimana kalimat yang dipakai, bagaimana menempatkan dan menulis sumber ke dalam teks berita secara keseluruhan.

Struktur Retoris dari wacana berita menggambarkan pilihan gaya yang dibuat oleh wartawan sehubungan dengan efek yang mereka harapkan. Ada beberapa elemen struktur retoris yang dipakai, dan yang paling penting adalah leksion, pemilihan dan pemakaian katakata tertentu untuk menandai atau menggambarkan peristiwa (Eriyanto, 2002).

Subjek penelitian ini adalah portal berita kompas.com dan republika.co.id. sedangkan objek penelitiannya adalah berita terkait kebijakan Arab Saudi yang memperbolehkan turis asing yang bukan pasangan suami isteri menginap sekamar.

Data yang telah dikumpulkan dianalisis dengan menggunakan skema model analisis framing Gerald M Kosicki dan Zhongdang Pan, yang terbagi dalam empat subkategori yakni sintaksis, skrip, tematik, dan retoris.

\section{HASIL PENELITIAN}

Media online Kompas.com merupakan kumpulan berita terkini yang dapat diakses melalui internet. Berita-berita yang terdapat dalam Kompas.com berbeda dengan yang ada dalam surat kabar harian Kompas. Pembaca Kompas.com dapat mengetahui kejadian-kejadian terbaru terjadi tanpa harus menunggu koran cetak terbit.

Republika.co.id atau lebih dikenal dengan ROL hadir sejak 17 Agustus 1995, dua tahun setelah Harian Republika terbit. ROL merupakan portal berita yang menyajikan informasi secara teks, audio, dan video, yang terbentuk berdasakan teknologi hipermedia dan hiperteks.

Dengan kemajuan informasi dan perkembangan sosial media, ROL kini hadir dengan berbagai fitur baru yang merupakan percampuran komunikasi media digital. Informasi yang disampaikan diperbarui secara berkelanjutan yang terangkum dalam sejumlah kanal.

Berikut ini adalah framing pemberitaan Kompas.com dengan judul: Izinkan Turis Tak Menikah Menginap Bareng dan Perempuan Boleh Menyetir, Mengapa Arab Saudi Sangat Terbuka?

Struktur Sintaksis. Kata turis bermakna pelancong; wisatawan; dan menjadi lebih spesifik ketika disandarkan kepada kata lain, seperti turis asing, turis domestik. Namun yang dimaksud dalam berita ini adalah turis asing, dengan indikator kata "visa" yang hanya diberikan kepada warga negara asing dan tidak diperlukan bagi warga lokal.

Secara sintaksis dapat dilihat berita ini menyampaikan Pemerintah Arab Saudi menerbitkan visa turis dan memperbolehkan wisatawan yang bukan pasangan suami isteri menginap dalam satu kamar, selain kebijakan diperbolehkannya menyetir mobil bagi perempuan. Judul dan lead secara tegas menyebutkan hal tersebut.

Turis bukan suami istri menginap dalam satu kamar dan mengemudi kendaraan bagi perempuan merupakan bentuk keterbukaan Arab Saudi, sebagai buah dari visi 2030 yang diluncurkan oleh Pangeran Muhammad Bin Salman. Negeri itu sedang berupaya mengurangi 
ketergantungan pada minyak dan melakukan diversifikasi ekonomi.

Struktur Skrip. Dalam pemberitaan di atas terdapat dua unsur yang kurang, yaitu (how) bagaimana peraturan yang berlaku di Arab Saudi sebelum dikeluarkannya kebijakan baru ini. Serta apakah (what) kebijakan ini juga berlaku pada turis lokal yang bukan pasangan suami isteri?

Struktruk Tematik. Secara garis besar kandungan berita di atas dapat dibagi menjadi dua isu besar: (1) kebijakan-kebijakan baru yang dikeluarkan Arab Saudi yang erat kaitannya dengan perempuan; (2) sosok dibalik kebijakan tersebut serta tujuan dari kebijakan tersebut.

Struktur Retoris. Berita ini ingin menyampaikan pesan bahwa Arab Saudi yang sekarang bukanlah Arab Saudi yang dulu ultra-konservatif, terutama mengenai isu-isu gender. Terlebih ketika menjadikan kebijakan terkait turis yang bukan pasangan suami isteri dapat menginap dalam satu kamar yang sangat bertententangan dengan syariat Islam yang selama ini diterapkan di Arab Saudi.

Sementara itu framing berita kedua dengan judul: Arab Saudi Izinkan Pasangan Turis Asing Tak Menikah Menginap di Satu Kamar Hotel adalah sebagai berikut:

Struktur Sintaksis. Judul berita secara tegas menyatakan bahwa Pemerintah Arab Saudi mengizinkan pasangan turis asing yang bukan pasangan suami istri bisa menginap di satu kamar hotel. Kebijakan itu merupakan bagian dari sejumlah kebijakan pemerintah Arab Saudi dalam menggenjot sektor pariwisata, sebagai salah satu upaya mendiversifikasi ekonomi, menjauh dari minyak bumi. Hal itu sejalan dengan Visi 2030 yang dicanangkan oleh Putra Mahkota Mohammed bin Salman.

Kemudian dijelaskan warga negara dari 49 negara berhak mendapatkan visa online maupun visa on-arrival, termasuk warga Amerika Serikat, Australia, dan sejumlah negara Eropa. Namun pemerintah Saudi memperingatkan turis yang melanggar "kesopanan publik", termasuk mengenakan pakaian yang tidak sopan dan memamerkan keintiman di depan publik, tetap dikenakan denda.

Struktur Skrip. Hampir sama dengan berita sebelumnya, di sini tidak dijelaskan bagaimana peraturan yang berlaku sebelum diterbitkannya kebijakan baru tersebut, serta apakah peraturan baru tersebut juga berlaku bagi turis lokal.

Struktur Tematik. Secara garis besar berita ini berfokus pada sektor pariwisata yang sedang digenjot oleh pemerintah Arab Saudi, salah satunya dengan memberikan sejumlah kelonggaran guna menarik turis asing berwisata ke Arab Saudi.

Struktur Retorik. Pesan yang sangat jelas dari berita ini adalah bahwa perubahan di Arab Saudi saat ini sudah menyentuh pada tatanan pengamalan syariat Islam, di mana pasangan yang bukan suami isteri sejatinya tidak diperbolehkan berkhalwat.

Framing berita ketiga dengan judul: Tawarkan Visa Turis hingga Izinkan Pasangan Tak Menikah Menginap Sekamar, Ini Cara Arab Saudi Genjot Sektor Pariwisata.

Struktur Sintaksis. Judul yang digunakan ini berupaya menyampaikan isi berita mengenai langkah-langkah pemerintah Arab Saudi dalam membangun sektor industri pariwisata, salahsatunya memperbolehkan turis asing yang bukan pasangan suami isteri menginap dalam satu kamar. Namun dalam berita ini tidak mencantumkan sumber berita ini didapatkan.

Struktur Skrip. Ditinjau dari stuktur skrip walaupun lengkap namun tetap saja berita yang disampaikan tidak terlalu memberikan informasi yang cukup bagi pembaca, diantarnya adalah apakah langkah yang diambil oleh pemerintah Arab Saudi terbatas pada yang disebutkan dalam berita saja, atau masih banyak langkah-langkah lain yang ditempuh terkait peningkatan sektor pariwisata di negara tersebut. 
Struktur Tematik. Berita ini lebih berfokus pada langkah-langkah yang ditempuh oleh pemerintah Arab Saudi dalam meningkatkan sektor pariwisata dan menarik turis asing untuk berwisata ke Arab Saudi.

Struktur Retorik. Meskipun sektor pariwsata adalah bagian yang penting dalam berita tersebut akan tetapi sekali lagi bahwa pemilihan kebijakan terkait pasangan tak menikah menginap sekamar memilki pesan bahwa Arab Saudi sudah sangat berubah dan berbeda dari sebelumnya.

Republika.co.id melihat kebijakan Arab Saudi itu dengan berbeda. Berikut ini adalah berita dengan judul: Judul: Arab Saudi Perbolehkan Pria dan Wanita Asing Sekamar Hotel.

Struktur Sintaksis. Pewarta Republika.co.id dengan tegas menyatakan Arab Saudi memperbolehkan perempuan dan pria asing yang bukan pasangan suami isteri untuk menginap bersama dalam satu kamar hotel, serta menjelaskan bahwa ini merupakan langkah dalam mengembangkan sektor pariwisata negara tersebut. Kebijakan itu merupakan turunan dari diterbitkannya visa wisata ke negara tersebut. Pewarta secara lengkap menukil berita ini dari sumber lokal dan juga internasional.

Struktur Skrip. Ditinjau dari struktur skrip berita ini sudah lengkap dan menjelaskan sesuai dengan judul yang diangkat.

Struktur Tematik. Isi berita berfokus pada kelonggaran yang diberikan kepada kaum hawa di negara tersebut, terutama di sektor pariwisata.

Struktur Retorik. Pesan yang ingin disampaikan dalam berita ini adalah bahwa Arab Saudi yang ultra-konservatif dapat berubah dengan drastis dan longgar demi menopang ekonomi negaranya, bahkan larangan khalwat (berdua-duaan) dengan yang bukan mahram pun diperbolehkan walaupun hanya untuk warga asing.

Berita Republika.co.id berikutnya dengan judul: Saudi Bolehkan Pria-Wanita Satu Kamar, MUI: Itu Sekularisme.

Struktur Sintaksis. Dalam berita ini, pewarta memberitakan tanggapan Ketua MUI Bidang Hubungan Luar Negeri, Muhyiddin Junaidi, terkait kebijakan Arab Saudi yang membolehkan pasangan pria dan wanita yang bukan suami isteri menginap dalam satu kamar, dengan jawaban sangat tegas bahwa itu merupakan sekularisme dan bukan kelonggaran.

MUI juga beranggapan kebijakan tersebut dapat mengurangi kesakralan Arab Saudi yang selama ini melekat padanya karena keberadaan dua masjid suci, sehingga kebijakan tersebut memicu keprihatinan MUI.

Struktur Skrip. Berita yang disampaikan sudah memenuhi seluruh struktur skrip, dimana dijelaskan apa tanggapan MUI terkait kebijakan Arab Saudi, siapa yang mengeluarkan tanggapan tersebut, kapan dan dimana statement tersebut diutarakan, kenapa tanggapan tersebut dapat keluar, dan bagaimana tanggapan ini keluar.

Struktur Tematik. Ditinjau dari struktur tematik, berita ini berfokus pada tangapan Ketua Majelis Ulama Indonesia (MUI) Bidang Hubungan Luar Negeri, Muhyiddin Junaidi, dan ditutup dengan penjelasan terkait kebijakan Arab Saudi dimaksud.

Struktur Retorik. Pewarta seakan-akan ingin menyampaikan pesan bahwa kebijakan yang diambil oleh Arab Saudi terkait pembolehan bagi pasangan yang bukan suami isteri adalah bentuk sekularisme, hal tersebut berdasarkan pada tanggapan yang dilontarakan oleh salah seorang Ketua Majelis Ulama Indonesia (MUI) Bidang Hubungan Luar Negeri, Muhyiddin Junaidi.

Selanjutnya adalah berita dengan judul: Puluhan Ribu Wisatawan Masuk Saudi dengan Visa Turis. 
Struktur Sintaksis. Sesuai dengan judul berita, pewarta memberitakan bahwa sekitar 24 ribu wisatawan asing memasuki Arab Saudi dengan visa turis dan ini terjadi dalam kurun waktu 10 hari sejak diumumkannya visa turis pada tanggal 27 September 2019. Berit itu merupakan bagian dari upaya untuk mendiversifikasi ekonomi negara tersebut. Disinggung pula kebijakan diperbolehkan pasangan asing yang belum menikah menginap dalam satu kamar. Dalam berita ini, disebutkan sumber berita asing yang dijadikan sebagai rujukan.

Struktur Skrip. Jika ditinjau dari struktur skrip, setidaknya ada satu hal yang kurang yaitu terkait (how) bagaimana cara untuk mendapatkan visa turis tersebut bagi selain bagi warga 49 negara yang disebutkan.

Struktur Tematik. Adapun secara unsur tematik berita ini lebih menekankan pada visa turis yang ditawarkan Arab Saudi guna mendukung sektor pariwisata negara tersebut.

Struktur Retorik. Pemilihan kata puluhan ribu wisatawan masuk ke Arab Saudi memberi pesan bahwa saat ini negara tersebut mulai didatangi warga negara asing dengan visa turis yang mana sebelumnya belum pernah diterbitkan visa jenis ini.

\section{KESIMPULAN}

Dari pemaparan di atas, terdapat perbedaan yang cukup tajam pada Kompas.com dan Republika.co.id dalam memberitakan satu hal yang sama. Pada Kompas.com, angle berita yang ditonjolkan adalah kebijakan yang dikeluarkan Arab Saudi, yaitu terkait pasangan pria dan wanita asing yang bukan suami isteri diperbolehkan menginap satu kamar. Dijelaskan bahwa hal tersebut merupakan salah satu langkah yang diambil oleh Arab Saudi dalam mendukung sektor pariwisata guna menyokong ekonominya dan menjauh dari ketergantungan minyak bumi.

Kompas.com juga selalu menyinggung sejumlah kebijakan lainnya terutama yang berkaitan dengan perempuan, sebagai informasi pelengkap bahwa negara petro dollar ini mengalami banyak perubahan. Namun, di setiap pemberitaannya, Kompas.com tidak menyebutkan sama sekali sumber berita yang didapatkan, padahal berita ini merupakan hasil kutipan dari media-media asing.

Adapun pemberitaan Republika.co.id, angle berita yang ditekankan adalah aspek hukum terkait pasangan pria wanita dari negara asing yang menginap satu kamar, di mana diketahui bahwa Arab Saudi merupakan salah satu negara yang menerapkan syariah Islam dan pengetahuan ini sangat melekat pada sebagian besar masyarakat muslim Indonesia. Kelebihan pemberitaan Republika.co.id adalah menyebutkan sumber-sumber berita yang dijadikan rujukan dalam berita.

Penyebutan sumber berita sangat diperlukan ketika mengambil berita dari sumber lain, apalagi berita tersebut adalah berita internasional yang memerlukan keakuratan dalam segala informasi yang disampaikan kepada pembaca.

\section{REFERENSI}

Al-Jazeera. (2019). Saudi Arabia to allow foreign couples to rent hotel rooms. Aljazeera.com. diakses dari https://www.aljazeera.com/news/2019/10/saudiarabia-foreign-couples-rent-hotel-rooms-191006154322189.html

Bungin, Burhan, (2003). Pornomedia Konstruksi Sosial Teknologi Telematika \& Perayaan Seks di Media Massa, Jakarta: Kencana.

Chomsky, N. \& Herman, S. (1998), Manufacturing Consent: The Political Economy of Mass Media, Patheon Books, New York.

Eriyanto, (2002). Analisis Framing:Konstruksi, ideologi dan Politik Media, Yogyakarta: LKiS 
Itah, Israr. (2019). Arab Saudi Perbolehkan Pria dan Wanita Asing Sekamar Hotel, Republika Online. Diakses dari https://internasional.republika.co.id/berita/pywf3e348/arab-saudiperbolehkan-pria-dan-wanita-asing-sekamar-hotel

Masyrafina, Idealisa. (2019). Puluhan Ribu Wisatawan Masuk Saudi dengan Visa Turis. Republika Online. Diakses dari https://republika.co.id/berita/pz3765328/puluhan-ribuwisatawan-masuk-saudi-dengan-visa-turis

Mukhtar, Umar. (2019). Saudi Bolehkan Pria-Wanita Satu Kamar, MUI: Itu Sekularisme. Republika Online. Diakses dari https://republika.co.id/berita/dunia-islam/islamnusantara/19/10/09/pz34w1320-saudi-bolehkan-priawanita-satu-kamar-mui-itusekularisme

Pavlik, Jhon, (2004). Converging Media. USA : Permission Department.

Perdana, Agni Vidya. (2019). Arab Saudi Izinkan Pasangan Turis Asing Tak Menikah Menginap di Satu Kamar Hotel. Kompas.com. diakses dari https://internasional.kompas.com/read/2019/10/07/14194941/arab-saudi-izinkanpasangan-turis-asing-tak-menikah-menginap-di-satu

Perdana, Agni Vidya. (2019). Tawarkan Visa Turis hingga Izinkan Pasangan Tak Menikah Menginap Sekamar, Ini Cara Arab Saudi Genjot Sektor Pariwisata. Kompas.com. diakses dari https://internasional.kompas.com/read/2019/10/09/06451311/tawarkan-visaturis-hingga-izinkan-pasangan-tak-menikah-menginap

Romli, A.S.M. \& Syamsul, A. (2012) Jurnalistik Online: Panduan Praktis Mengelola Media Online. Bandung, Nuansa Cendekia.

Schudson, Michael. (1995). The Power of News. London: Harvard University Press

Severin, Wener J. Tankard, James. W, 2014. Jakarta: Kencana.

Sobur, Alex, (2001). Analisis Teks Media, Bandung: Remaja Rosdakarya

Sugiyono, (2019). Metode Penelitian Kuantitatif, Kualitatif dan R\&D, Bandung: Alfabeta.

Utomo, Ardi Priyatno. (2019). Izinkan Turis Tak Menikah Menginap Bareng dan Perempuan

Boleh Menyetir, Mengapa Arab Saudi Sangat Terbuka?. Kompas.com. diakses dari https://internasional.kompas.com/read/2019/10/08/06000071/izinkan-turis-takmenikah-menginap-bareng-dan-perempuan-boleh-menyetir

Yunus, Syafrudin, (2010). Jurnalistik Terapan, Bogor: Ghalia Indonesia. 